Tüketicilerin sosyo-demografik özelliklerine göre deniz ve tatlısu balığı tüketim tercihleri

\section{Determination of consumption preferences of seafish and freshwater fish according to socio-demographic characteristics of the consumers}

\section{ÖZET}

Bu çalışmada Adana ilindeki su ürünleri tüketicilerinin sosyo-demografik özelliklerine göre deniz balığı ile tatlısu balığı tüketim davranışları arasındaki benzerlikleri ve farklılıkları ortaya konulmuştur. Çalışmamızda Adana'da toplam 407 kişi ile anket yapılmıştır. Ankete katılan 407 kişiden 347 sinin su ürünleri tükettiği 60'ının ise su ürünleri tüketmediği tespit edilmiştir. Veriler SPSS.21.0 paket programı kullanılarak yüzde frekans değerleri bulunmuştur. Elde edilen bulgulara göre deniz balığ $\% 83,1$ 'lik bir oranla erkeklerde en çok tüketilirken tatlısu balığı ise \%20,9'luk oranla kadınlarda daha çok tüketilmektedir. Yaşa göre ise yine deniz balığ 1 tüketimi en çok 45-54 yaş aralığında $\% 95,6$ oranında tüketilirken tatlısu balığı ise $\% 18,1$ 'lik oranla 25 yaş altı grupta tüketilmektedir. Eğitim durumuna göre ilkokul-ortaokul mezunu grup \%86,2'lik oranla deniz balığını tüketirken, tatlı su balığında ise \%25'lik oranla lisansüstü eğitime sahip grup en çok tüketmektedir. \%88,9'luk oranla esnaf grup en çok deniz balığını tercih ederken, \%25,9'luk oranla ev hanımları tatlısu balığını en çok tercih eden grup bulunmuştur. Gelir durumuna göre yüksek gelir grubu olan bireyler deniz balığını daha çok tercih ederken, yüksek ve düşük gelir grubu bireyler tatlısu balığını diğerlerine göre daha çok tercih etmektedir. Hane birey sayısı az olan bireyler deniz balığını daha çok tercih ederken, hane birey sayısı fazla olan bireyler tatlısu balığını daha çok tercih etmektedir. Sonuçlar incelendiğinde tüketicilerin sosyo demografik özelliklerine göre deniz balığ tüketimini daha çok tercih ettikleri ortaya çıkmış olup Tatlısu balıklarının da yüksek oranlarda tükettikleri bulgularına ulaşı1mıştır.

Anahtar Kelimeler: Deniz balığı, Tatlısu balığı, Tüketim tercihleri, Tüketici, Adana

\section{ABSTRACT}

In this study, the similarities and differences between the consumption preferences of sea fish and freshwater fish according to the socio-demographic characteristics of the seafood consumers have been revealed. For this purpose, a face-to-face survey was conducted with 407 people in Adana. In the study, it was found that 347 out of 407 people consumed aquaculture and 60 did not consume aquatic products. Percentage frequency values of the data were found by using SPSS.21.0 package program. According to the findings, sea fish is consumed most in males with a rate of $83.1 \%$ while freshwater fish is consumed more in women with a rate of $20.9 \%$. According to age, sea fish consumption is consumed by $95.6 \%$ in the $45-54$ age range, while the freshwater fish is consumed in the under 25 age group with a rate of $18.1 \%$. According to the educational level, primary and secondary school graduates consumed sea fish with a ratio of $86.2 \%$, while the group with graduate education consumed the most with freshwater fish. $88.9 \%$ of the craftsmen group preferred the most sea fish, while $25.9 \%$ of the housewives the most preferred group of freshwater fish emerged. According to income status, individuals with high income group prefer sea fish more, while middle and low income individuals prefer freshwater fish more than others. While individuals with small households prefer sea fish more, individuals with large households prefer freshwater fish more. When the results were examined, it was found out that consumers preferred sea fish consumption more than their sociodemographic characteristics and it was found that freshwater fish consumed at high rates.

Keywords: Sea fish, Fresh water fish, Consumption preferences, Consumer, Adana

Sangün, L., Güney, O.I. (2019). Tüketicilerin sosyo-demografik özelliklerine göre deniz ve tatlısu balığı tüketim tercihleri. J Adv VetBio Sci Tech, 4(3), 105111. https://doi.org/10.31797/vetbio.630363

\section{Research Article}

\section{Levent Sangün ${ }^{1}$ Osman İnanç Güney ${ }^{2}$}

Çukurova Üniversitesi Adana Meslek Yüksekokulu ${ }^{1}$ ORCID 0000-0002-2363-8977 ${ }^{2}$ ORCID 0000-0002-8467-2079

\section{Correspondence}

Doç. Dr. Leven Sangün

Çukurova Üniversitesi Adana Meslek Yüksekokulu e-mail: leventsangun@gmail.com

Article info

Submission: 07-09-2019

Accepted: 14-12-2019

Online first published: $26-10-2019$

Published: 30-12-2019

This work is licensed under a Creative Commons Attribution 4.0 International License (c) (4) 


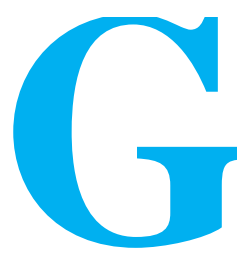

iriș

Üç tarafı denizlerle çevrili olan ülkemiz, insan beslenmesinde çok önemli bir yeri olan su ürünleri ve özellikle balık çeşitliliği açısından zengin bir ülkedir (Akbay ve ark., 2013). Su ürünleri protein, vitamin, mineral ve elementler açısından son derece zengin besinler olması nedeniyle insan beslenmesinde önemli yer tutmaktadır (Sayılı ve ark., 1999; Adıgüzel ve ark., 2009).

Dünya nüfusunun hızla artması ve insanların yeni protein kaynaklarına yönelmesi sonucu balığın besin maddeleri arasındaki yeri daha fazla değer kazanmıştır. Bir besin maddesinin kalitesi, taşıdığ proteinin sindirim kanalında enzim etkisiyle çabuk çözünebilir nitelikte olmasına bağlıdır. Balıketi proteinleri çabuk çözünme, kolay sindirilebilme özellikleriyle hem yetişme çağında olanlar, hem de bedeni ve zihinsel faaliyetlerde bulunanlar için büyük önem taşımaktadır (Balık ve ark., 2013).

İnsan beslenmesinde önemli bir yeri olan su ürünleri sağlıklı beslenmeye katkısı, sanayiye hammadde sağlaması, işlenerek pazarlanması ve ihracatıyla önemli bir gıda kolunu oluşturmaktadır (Dağtekin ve ark, 2007). Bunun yanı sıra çok sayıda protein, vitamin ve mineral içeren su ürünlerinin insan vücudu için önemli olduğu özellikle omega 3 ve omega 6'nın kanser ve koroner kalp hastalığından koruduğu bilinmektedir (Atar ve Alçiçek, 2009).

Vücudumuz, çok besleyici olan balıketinin \% 90'inı kullanabilmektedir. Ayrıca, balıketi, kırmızı ete oranla daha az yağ içermektedir. Balıketi, vücut direncinin artmasını sağladığı gibi, içerdiği yüksek orandaki kalsiyum, fosfor ve iyot ile vücudun mineral denge sinin korunmasina da yardımcı olmaktadır. Vücudun kış mevsiminde daha da $\operatorname{artan} \mathrm{A}, \mathrm{B} 1, \mathrm{~B} 2$ ve D vitamini ihtiyacını da balı tüketimi ile karşılamak mümkündür (Hecer, 2012).

Tüketicilerin özellikle gelişmiş ülkelerde balıketine olan meyilleri, bilinçli toplumların "dengeli beslenme" sloganını benimsemelerinden kaynaklanmaktadır. Taze tüketimde meydan gelen artışın sebebi ise, teknolojinin ilerlemesiyle ucuz maliyette taze ürünün tüketiciye ulaştırılması ve insanların doğal (katkısız) ürün tüketmek istemeleridir (Çolakoğlu ve ark., 2006).

$\mathrm{Bu}$ çalışmanın amacı, Adana ilindeki su ürünleri tüketicilerinin sosyo-demografik özelliklerine göre deniz balığı ile tatlısu balığı tüketim davranışları arasındaki benzerlikleri ve farklılıkları ortaya koyulmaktır.

\section{MATERYAL VE METOD}

Çalışmada su ürünleri tüketicilerinin sosyo demografik özelliklerine göre deniz balığı ile tatlısu balığı tüketim davranışları arasındaki benzerlikleri ve farklılıkları ortaya koyulmaya çalışılmıştır. Çalışma Adana ilinde gerçekleştirilmiştir. Çalışmanın örneklem büyüklüğü ise aşağıda verilen formül yardımıyla hesaplanmıştır (Güney ve Sangün, 2017).

$$
n=\frac{p \cdot(1-p)}{(\mathrm{e} / \mathrm{Z})^{2}}
$$

Formülde $\mathrm{n}$ : örnek hacmini, $\mathrm{p}$ incelenen olayın görüş sıklığını, e hata payı oranını, z ise güven aralığını ifade etmektedir. p (1p)'nin en yüksek değeri esas alınarak hata payı e $=\% 5$ ve güven aralığının \% 95 kabul edildiği hesaplamada sonuç 384 kişi olarak çıkmıştır. Çalışmamız toplam 407 kişi ile anket yapılmıştır. $\mathrm{Bu} 407$ kişiden 347 sinin su ürünleri tükettiği 60'1nın ise su ürünleri tüketmediği tespit edilmiştir. 
Çalışma sonucunda elde edilen veriler yüzde frekans tablosu ile değerlendirilmiştir. Veriler SPSS 21.0 istatistik analiz programı ile analiz edilmiştir (Sangün ve Güney, 2018).

\section{BULGULAR}

Çalışmamızda su ürünleri tüketicilerinin sosyo demografik özelliklerine göre deniz balığı ile tatlısu balığı tüketim davranışları arasındaki benzerlikleri ve farklılıkları ortaya konulmuştur. Çalışmamızda Adana'da toplam 407 kişi ile yüz yüze anket yapılmış olup ankete katılan bireylerin 347 sinin su ürünleri tükettiği 60'ının ise su ürünleri tüketmediği tespit edilmiştir. Su ürünleri tüketen bu 347 kişinin sosyo-demografik özelliklerinden cinsiyet faktörlerine ait deniz balığı ve Tatlısu balığı tüketim tercihlerine ait yüzde frekans değerleri Tablo 1'de verilmiştir.

Tablo 1. Tüketicilerin Cinsiyet Göre Deniz ve Tatlısu Balığı Tüketim Tercihlerine ait Yüzde Frekans Tablosu

\begin{tabular}{|lccc|}
\hline & Erkek & Kadın & Toplam \\
N $(\%)$ & \\
\hline Deniz & N $(\%)$ & $12(3,5)$ \\
Hiç Bir Zaman & $4(1,9)$ & $8(5,9)$ & $10(2,9)$ \\
Nadiren & $4(1,9)$ & $6(4,5)$ & $41(11,8)$ \\
Kimi Zaman & $28(13,1)$ & $13(9,7)$ & $284(81,8)$ \\
Her Zaman & $177(83,1)$ & $107(79,9)$ & $347(100)$ \\
Total & $213(100)$ & $134(100)$ & $147(42,4)$ \\
Tatlısu & & & $31(8,9)$ \\
Hiç Bir Zaman & $93(43,7)$ & $54(40,3)$ & $114(32,9)$ \\
Nadiren & $19(8,9)$ & $12(9)$ & $55(15,8)$ \\
Kimi Zaman & $74(34,7)$ & $40(29,8)$ & $347(100)$ \\
Her Zaman & $27(12,7)$ & $28(20,9)$ & \\
Total & $213(100)$ & $134(100)$ & \\
\hline
\end{tabular}

$\mathrm{Su}$ ürünleri tüketen tüketicilerin sosyodemografik özelliklerinden yaş faktörlerine ait deniz balığı ve tatlı su balığı tüketim alışkanlıklarına ait yüzde frekans değerleri Tablo 2'de verilmiştir.

Su ürünleri tüketen tüketicilerin sosyodemografik özelliklerinden eğitim durumlarına göre deniz ve tatlısu balığı tüketim alışkanlıklarına ait yüzde frekans değerleri Tablo 3'te verilmiştir.

Tüketicilerin sosyo-demografik özelliklerinden meslek gruplarına göre deniz balığı ve tatlı su balığı tüketim alışkanlıklarına ait yüzde frekans değerleri Tablo 4'te verilmiştir.

Tablo 2. Tüketicilerin Yaş Dağılımlarına Göre Deniz ve Tatlısu Balığı Tüketim Tercihlerine ait Yüzde Frekans Tablosu

\begin{tabular}{|lcccccc|}
\hline \multicolumn{1}{|c}{$\mathbf{2 5}$} & $\mathbf{2 5 - 3 4}$ & $\mathbf{3 5 - 4 4}$ & $\mathbf{4 5 - 5 4}$ & $\mathbf{5 4}$ & Toplam \\
\hline Deniz & $\mathbf{N}(\mathbf{\%})$ & $\mathbf{N}(\mathbf{\%})$ & $\mathbf{N}(\mathbf{\%})$ & $\mathbf{N}(\mathbf{\%})$ & $\mathbf{N}(\mathbf{\%})$ & $\mathbf{N}(\mathbf{\%})$ \\
\hline Hiç Bir Zaman & $7(3,8)$ & $5(5,9)$ & $0(0)$ & $0(0)$ & $0(0)$ & $12(3,5)$ \\
Nadiren & $7(3,8)$ & $2(2,4)$ & $1(2,1)$ & $0(0)$ & $0(0)$ & $10(2,9)$ \\
Kimi Zaman & $25(13,8)$ & $12(14,1)$ & $2(4,3)$ & $1(4,4)$ & $1(10)$ & $41(11,8)$ \\
Her Zaman & $143(78,6)$ & $66(77,6)$ & $44(93,6)$ & $22(95,6)$ & $9(90)$ & $284(81,8)$ \\
Total & $182(100)$ & $85(100)$ & $47(100)$ & $23(100)$ & $10(100)$ & $347(100)$ \\
\hline Tatlisu & & & & & \\
\hline Hiç Bir Zaman & $84(46,2)$ & $35(41,2)$ & $17(36,2)$ & $9(39,1)$ & $2(20)$ & $147(42,4)$ \\
Nadiren & $13(7,1)$ & $7(8,2)$ & $6(12,7)$ & $2(8,7)$ & $3(30)$ & $31(8,9)$ \\
Kimi Zaman & $52(28,6)$ & $28(33,0)$ & $21(44,7)$ & $9(39,1)$ & $4(40)$ & $114(32,9)$ \\
Her Zaman & $33(18,1)$ & $15(17,6)$ & $3(6,4)$ & $3(13,1)$ & $1(10)$ & $55(15,8)$ \\
Total & $182(100)$ & $85(100)$ & $47(100)$ & $23(100)$ & $10(100)$ & $347(100)$ \\
\hline
\end{tabular}


Tablo 3. Tüketicilerin Eğitim Durumlarına Göre Deniz ve Tatlısu Balığı Tüketim Tercihlerine ait Yüzde Frekans Tablosu

\begin{tabular}{|c|c|c|c|c|c|c|}
\hline & $\begin{array}{c}\text { Okur yazar değil } \\
\text { N }(\%)\end{array}$ & $\begin{array}{c}\text { İlk Öğretim } \\
\mathbf{N}(\%)\end{array}$ & $\begin{array}{l}\text { Lise } \\
\mathbf{N}(\%)\end{array}$ & $\begin{array}{c}\text { Üniversite } \\
\mathbf{N}(\%)\end{array}$ & $\begin{array}{c}\text { Lisansüstü } \\
\mathbf{N}(\%)\end{array}$ & $\begin{array}{l}\text { Total } \\
\mathbf{N}(\%)\end{array}$ \\
\hline \multicolumn{7}{|l|}{ Deniz } \\
\hline Hiç Bir Zaman & $0(0)$ & $2(3,5)$ & $5(2,7)$ & $5(5,2)$ & $0(0)$ & $12(3,5)$ \\
\hline Nadiren & $0(0)$ & $2(3,5)$ & $6(3,2)$ & $1(1,0)$ & $1(25,0)$ & $10(2,9)$ \\
\hline Kimi Zaman & $0(0)$ & $4(6,8)$ & $23(12,3)$ & $14(14,6)$ & $0(0)$ & $41(11,8)$ \\
\hline Her Zaman & $2(100)$ & $50(86,2)$ & $153(81,8)$ & $76(79,2)$ & $3(75,0)$ & $284(81,8)$ \\
\hline Total & $2(100)$ & $58(100)$ & $187(100)$ & $96(100)$ & $4(100)$ & 347 \\
\hline \multicolumn{7}{|l|}{ Tatlısu } \\
\hline Hiç Bir Zaman & $1(50)$ & $18(31,0)$ & $88(47,1)$ & $37(38,5)$ & $3(75,0)$ & $147(42,4)$ \\
\hline Nadiren & $0(0)$ & $8(13,8)$ & $13(6,9)$ & $10(10,4)$ & $0(0)$ & $31(8,9)$ \\
\hline Kimi Zaman & $1(50)$ & $25(43,1)$ & $58(31,0)$ & $30(31,3)$ & $0(0)$ & $114(32,9)$ \\
\hline Her Zaman & $0(0)$ & $7(12,1)$ & $28(15,0)$ & $19(19,8)$ & $1(25,0)$ & $55(15,8)$ \\
\hline Total & $2(100)$ & $58(100)$ & $187(100)$ & $96(100)$ & $4(100)$ & $347(100)$ \\
\hline
\end{tabular}

Tablo 4. Tüketicilerin Meslek Gruplarına Göre Deniz ve Tatlısu Balığı Tüketim Tercihlerine ait Yüzde Frekans Tablosu

\begin{tabular}{|c|c|c|c|c|c|c|c|c|c|}
\hline & İşçi & Memur & $\begin{array}{c}\text { Esnaf } \\
\text { Zanaatkâr }\end{array}$ & $\begin{array}{l}\text { Serbest } \\
\text { meslek }\end{array}$ & $\begin{array}{c}\text { Özel } \\
\text { sektör }\end{array}$ & Öğrenci & $\begin{array}{c}\text { Ev } \\
\text { hanımı }\end{array}$ & İşsiz & Total \\
\hline & $\mathbf{N}(\%)$ & $\mathbf{N}(\%)$ & $\mathbf{N}(\%)$ & $\mathbf{N}(\%)$ & $\mathbf{N}(\%)$ & $\mathbf{N}(\%)$ & $\mathbf{N}(\%)$ & $\mathbf{N}(\%)$ & $\mathbf{N}(\%)$ \\
\hline \multicolumn{10}{|l|}{ Deniz } \\
\hline Hiç Bir Zaman & $0(0)$ & $0(0)$ & $0(0)$ & $2(4,2)$ & $2(2,9)$ & $0(0)$ & $7(13,0)$ & $1(2,0)$ & $12(3,5)$ \\
\hline Nadiren & $1(2,9)$ & $0(0)$ & $1(3,7)$ & $1(2,1)$ & $1(1,5)$ & $3(6,8)$ & $2(3,7)$ & $1(2,0)$ & $10(2,9)$ \\
\hline Kimi Zaman & $6(18,2)$ & $4(18,2)$ & $2(7,4)$ & $4(8,3)$ & $7(10,3)$ & $4(9,1)$ & $8(14,8)$ & $6(12,2)$ & $41(11,8)$ \\
\hline Her Zaman & $28(81,8)$ & $18(81,8)$ & $24(88,9)$ & $41(85,4)$ & $58(85,3)$ & $37(84,1)$ & $37(68,5)$ & $41(83,8)$ & $284(81,8)$ \\
\hline Total & $35(100)$ & $22(100)$ & $27(100)$ & $48(100)$ & $68(100)$ & $44(100)$ & $54(100)$ & $49(100)$ & $347(100)$ \\
\hline \multicolumn{10}{|l|}{ Tatlısu } \\
\hline Hiç Bir Zaman & $13(37,1)$ & $9(40,9)$ & $11(40,7)$ & $23(47,9)$ & $20(29,4)$ & $28(63,6)$ & $17(31,5)$ & $26(53,1$ & $147(42,3)$ \\
\hline Nadiren & $1(2,9)$ & $2(9,1)$ & $2(7,4)$ & $6(12,5)$ & $8(11,8)$ & $3(6,8)$ & $5(9,3)$ & $4(8,2)$ & $31(8,9)$ \\
\hline Kimi Zaman & $15(42,9)$ & $9(40,9)$ & $13(48,2)$ & $12(25,0)$ & $26(38,2)$ & $8(18,2)$ & $18(33,3)$ & $13(26,5)$ & $114(32,9)$ \\
\hline Her Zaman & $6(17,1)$ & $2(3,7)$ & $1(3,7)$ & $7(14,6)$ & $14(20,6)$ & $5(11,4)$ & $14(25,9)$ & $6(12,2)$ & $55(15,9)$ \\
\hline Total & $35(100)$ & $22(100)$ & $27(100)$ & $48(100)$ & $68(100)$ & $44(100)$ & $54(100)$ & $49(100)$ & $347(100)$ \\
\hline
\end{tabular}

Su ürünleri tüketen tüketicilerinin sosyodemografik özelliklerinden gelir durumlarına göre deniz ve Tatlısu balığı tüketim alışkanlıklarına ait yüzde frekans değerleri Tablo 5'te verilmiştir.
$\mathrm{Su}$ ürünleri tüketen tüketicilerin sosyodemografik özelliklerinden hane birey sayılarına göre deniz ve Tatlısu balığ tüketim alışkanlıklarına ait yüzde frekans değerleri Tablo 6' da verilmiştir.

Tablo 5. Tüketicilerin Gelir Durumlarına Göre Deniz ve Tatlısu Balığı Tüketim Tercihlerine ait Yüzde Frekans Tablosu

\begin{tabular}{|c|c|c|c|c|c|c|c|}
\hline & $\begin{array}{c}\text { Yok } \\
\text { N }(\%)\end{array}$ & $\begin{array}{l}1001< \\
\mathbf{N}(\%)\end{array}$ & $\begin{array}{c}1001-2000 \\
N(\%)\end{array}$ & $\begin{array}{c}2001-3000 \\
N(\%)\end{array}$ & $\begin{array}{c}3001-4000 \\
N(\%)\end{array}$ & $\begin{array}{l}4000> \\
N(\%)\end{array}$ & $\begin{array}{l}\text { Total } \\
\mathbf{N}(\%)\end{array}$ \\
\hline \multicolumn{8}{|l|}{ Deniz } \\
\hline Hiç Bir Zaman & $8(6,9)$ & $0(0)$ & $3(2,2)$ & $1(2,6)$ & $0(0)$ & $0(0)$ & $12(3,5)$ \\
\hline Nadiren & $5(4,3)$ & $1(2,9)$ & $4(3,0)$ & $0(0)$ & $0(0)$ & $0(0)$ & $10(2,9)$ \\
\hline Kimi Zaman & $16(13,8)$ & $2(5,7)$ & $15(11,1)$ & $7(17,9)$ & $0(0)$ & $1(7,1)$ & $41(11,8)$ \\
\hline Her Zaman & $87(75,0)$ & $32(91,4)$ & $113(83,7)$ & $31(79,5)$ & $8(100)$ & $13(92,9)$ & $284(81,8)$ \\
\hline Total & $116(100)$ & $35(100)$ & $135(100)$ & $39(100)$ & $8(100)$ & $14(100)$ & $347(100)$ \\
\hline \multicolumn{8}{|l|}{ Tatlısu } \\
\hline Hiç Bir Zaman & $55(47,4)$ & $14(40,0)$ & $54(40,0)$ & $15(38,5)$ & $2(25,0)$ & $7(50,0)$ & $147(42,4)$ \\
\hline Nadiren & $6(5,2)$ & $4(11,4)$ & $12(8,9)$ & $5(12,8)$ & $3(37,5)$ & $1(7,2)$ & $31(8,9)$ \\
\hline Kimi Zaman & $32(27,6)$ & $14(40,0)$ & $48(35,6)$ & $14(35,9)$ & $3(37,5)$ & $3(21,4)$ & $114(32,9)$ \\
\hline Her Zaman & $23(19,8)$ & $3(8,6)$ & $21(15,5)$ & $5(12,8)$ & $0(0)$ & $3(21,4)$ & $55(15,8)$ \\
\hline Total & $116(100)$ & $35(100)$ & $135(100)$ & $39(100)$ & $8(100)$ & $14(100)$ & $347(100)$ \\
\hline
\end{tabular}


Tablo 6. Tüketicilerin Hane Birey Sayısına Göre Deniz ve Tatlısu Balığı Tüketim Tercihlerine ait Yüzde Frekans Tablosu

\begin{tabular}{|c|c|c|c|c|c|}
\hline & $\begin{array}{r}1 \\
\mathbf{N}(\%)\end{array}$ & $\begin{array}{r}2-3 \\
N(\%)\end{array}$ & $\begin{array}{r}4-5 \\
N(\%)\end{array}$ & $\begin{array}{r}\text { 5> } \\
\mathbf{N}(\%)\end{array}$ & \begin{tabular}{c|} 
Toplam \\
$\mathbf{N}(\%)$
\end{tabular} \\
\hline \multicolumn{6}{|l|}{ Deniz } \\
\hline Hiç Bir Zaman & $0(0)$ & $4(4,6)$ & $4(2,0)$ & $4(7,6)$ & $12(3,5)$ \\
\hline Nadiren & $1(8,3)$ & $2(2,3)$ & $6(3,1)$ & $1(1,9)$ & $10(2,9)$ \\
\hline Kimi Zaman & $0(0)$ & $7(8,1)$ & $29(14,9)$ & $5(9,4)$ & $41(11,8)$ \\
\hline Her Zaman & $11(91,7)$ & $74(85,0)$ & $156(80,0)$ & $43(81,1)$ & $284(81,8)$ \\
\hline Total & $12(100)$ & $87(100)$ & $195(100)$ & $53(100)$ & $347(100)$ \\
\hline \multicolumn{6}{|l|}{ Tatlısu } \\
\hline Hiç Bir Zaman & $7(58,3)$ & $32(36,8)$ & $80(41,0)$ & $28(52,8)$ & $147(42,4)$ \\
\hline Nadiren & $1(8,3)$ & $7(8,1)$ & $21(10,8)$ & $2(3,8)$ & $31(8,9)$ \\
\hline Kimi Zaman & $4(33,4)$ & $32(36,8)$ & $65(33,3)$ & $13(24,5)$ & $114(32,9)$ \\
\hline Her Zaman & $0(0)$ & $16(18,3)$ & $29(14,9)$ & $10(18,9)$ & $55(15,8)$ \\
\hline Total & $12(100)$ & $87(100)$ & $195(100)$ & $53(100)$ & $347(100)$ \\
\hline
\end{tabular}

\section{SONUÇ VE ÖNERIILER}

Bulgular incelendiğinde, Tablo 1'de, cinsiyete göre tüketicilerin deniz balığı ve ya tatlısu balığı tüketim alışkanlıkları ile ilgili soruya verilen cevaplar incelendiğinde, tüketicilerin büyük bir oranlar deniz balığ tükettiği ortaya çıkmıştır. Erkek bireylerin verdiği cevaplara bakarsak bunların \%83,1'i deniz balığını her zaman tercih ettiklerini söylerken tatlısu balığında ise bu aran \%12,7 olarak tespit edilmiştir. Kadın tüketicilerin verdiği cevaplarda ise tüketicilerin $\% 79,9$ 'u deniz balığını her zaman tercih ettiğini bildirirken bu oran Tatlısu balığında ise \%20,9 olarak çıkmıştır.

Tablo 2'de, deniz ve tatlısu balığ tüketen tüketicilerin yaş dağılımlarına göre tüketim tercihlerine ait frekans tablosu verilmiştir. Tabloya ait sonuçlar incelendiğinde, her yaş grubuna ait tüketicilerin deniz balığını daha çok tükettiği tespit edilmiştir. 25 yaş altı tüketicilerin \%78,6'sı deniz balığını her zaman tercih ettiklerini belirtirken, Tatlisu balığı için \%18,1'inin her zaman tercih ettiklerini bildirmişlerdir. 25-34 yaş grubu tüketicilerin her zaman deniz balığı tercih etme oranları \%77,6 iken Tatlısu tercih etme oranları ise \%17,6 çıkmıştır. 35-44 yaş aralığını deniz ve tatlısu balığı tercih oranlarını incelediğimizde tüketicilerin \%93,6'sı deniz balığını her zaman tercih ederken tatlısu balığını tercih edenlerin oranı $\% 6,4$ çıkmıştır. 45-54 yaş aralığını incelediğimizde ise tüketicilerin \%90'1 deniz balığını her zaman tercih ettiklerini bildirir iken tatlı su balığını her zaman tüketenlerin oranı \%13,1 çıkmıştır. 54 yaştan büyük tüketicileri incelediğimizde bunların $\% 81,8^{\prime}$ i her zaman deniz balığını tercih ettikleri, tatlısu balığını ise \%10'u her zaman tercih ettiğini bildirmişti.

Tablo 3'de, tüketicilerin eğitim durumlarına göre deniz balığı ve tatlısu balığı tüketim tercihlerine ait frekans tablosu incelendiğinde, okuryazar olmayanlarda deniz balığ 1 tüketimi oranı her zaman iken tatlısu balığı tüketimi aynı aranda olmadığ tespit edilmiştir. İlkokul-ortaokul mezunlarında, deniz balığını tüketimi $\% 86,2$ oranında her zaman iken tatlısu balığ tüketimi $\% 12,1$ oranında her zaman çıkmıştır. Lise eğitimine sahip olan tüketicilerde deniz balığı tercih oranı her zaman \%81,8, tatlısu balığı \%15 oranında her zaman çıkmıştır. Üniversite mezunlarının deniz balığ tercihleri \% 79,2 her zaman iken tatlı su balığı tercihleri \%19,8 her zaman çıkmıştır. Lisansüstü eğitimine sahip tüketicilerin deniz balığ 
oranında her zaman iken tatlısu balığı tercihleri \%25 oranında her zaman çıkmıştır.

Tablo 4'te, meslek gruplarına göre tüketicilerin deniz balığı ve tatlısu balığı tercihlerini tespit etmek için oluşturulan yüzde değerleri incelendiğinde, meslek gruplarından iş̧̧i sınıfına ait tüketicilerin \%81,8'i her zaman deniz balığ tercih ederken tatlısu balığını her zaman tercih etme oranları \%17,1 olarak çıkmıştır. Memurların \%81,8'i her zaman deniz balığını tüketmeyi tercih ederken tatlısu balığını \%3,7'sinin her zaman tercih ettiği ortaya çıkmıştır. Esnaf ve zanaatkarlar da ise bu meslek grubuna ait bireylerin \%88,9'u her zaman deniz balığı tüketirken tatlısu balığını her zaman tüketen oranı ise \%3,7 olarak çıkmıştır. Serbest meslek grubunda ise her zaman deniz balığı tercih edenlerin oranı $\% 85,4$ tatlı su balığı her zaman tercih edenlerin oranı ise $\% 14,6$ olarak bulunmuştur. Özel sektörde çalışan meslek gruplarında ise her zaman deniz balığını tercih edenlerin oran $1 \% 85,3$, her zaman tatl su balığını tercih edenlerin oranı ise \%20,6 çıkmıştır. Öğrencilerde ise her zaman deniz balığını tercih edenlerin oranı $\% 84,1$, her zaman tatlısu balığını tercih edenlerin oranı ise \%11,4 çıkmıştır. Ev hanımlarında her zaman deniz balığını tercih etme oranı $\% 68,5$, her zaman Tatlısu balığını tercih etme oranı \%25,9 olarak tespit edilmiştir. İşsizlerde yine her zaman deniz balığını tercih etme oranı $\% 83,8$, her zaman tatlisu balığını tercih etme oranı ise \%12,2 olarak bulunmuştur.

Tablo 5'te, gelir durumlarına göre tüketicilerin deniz balığı ve tatlısu balığ tercihlerine ait yüzde değerler incelendiğinde, belli geliri olmayan gruba ait biteyler \%75 oranında her zaman deniz balığı, \%19,8 oranında ise tatlı sur balığını tercih ettikleri ortaya çıkmıştır. Geliri 1001
TL'nin altında olan tüketicilerin $\% 91,4$ 'ü her zaman deniz balığını tercih ederken $\% 8,6$ 'lık oran isen her zaman tatlı su balığını tercih ettiğini bildirmiştir. Geliri 1001-2000TL arası olana tüketicilerin \%83,7'si, her zaman deniz balığını tercih ederken, her zaman tatlı su balığını tercih edenlerin oranı $\% 15,5$ çıkmıştır. Geliri 2001-3000TL olan tüketicilerin \%79,5'i her zaman deniz balığını tercih ettiği, tatlı su balığını her zaman tercih edenlerin oran 1 ise $\% 12,8$ çıkmıştır. Geliri 3001-4000 TL arası olan tüketicilerin her zaman deniz balığını tercih eme oranı \%100 çıkmıştır. Geliri 4000 TL'nin üstünde olana tüketicilerin deniz balığını her zaman tercih etme oranları $\% 92,9$, Tatlısu balığını her zaman tercih etme oranı ise $\% 21,4$ çıkmıştır.

Sonuç olarak, deniz ve tatlısu balıklarının bulunurluğu, çeşitliliği, taze olması ve tazeliğinin korunması tüketicilerin bu ürünleri tüketme alışkanlıkları ve davranışlarını etkileyecektir. $\mathrm{Bu}$ ürünlerin gıda güvenliği çerçevesinde korunması ve sertifikalandırılması ayrıca tüketimde artışı sağlayacaktır.

\section{TEŞEKKÜR}

Bu çalışma, Çukurova Üniversitesi Bilimsel Araştırma Projeleri Birimi tarafından desteklenen FBA-2019-11865 projesinden elde edilen veriler yardımıla gerçekleştirilmiştir.

\section{KAYNAKLAR}

\section{Adıgüzel F, Civelek O, Sayılı M, Büyükbay}

E.O. (2009). Tokat İli Almus İlçesinde ailelerin balık tüketim durumu. Gaziosmanpaşa Üniversitesi Ziraat Fakültesi Dergisi, 26(2): 35-43.

Alçiçek, Z., Atar, H.H. (2009). Sürdürülebilir Su Ürünleri. Ulusal Su Günleri, s. 112, 29 Eylül-1 Ekim, Elazığg, Türkiye

Akbay, C., Meral, Y., Yılmaz, H.İ. Gözek, S. (2013). Türkiye'de Ailelerin Su Ürünleri 
Tüketiminin Ekonomik Analizi. KSU J. Nat. Sci., 16(3), 1-7.

Balık, I. Yardımcı, C., Turhan, O. (2013). Ordu İli Fatsa ve Aybastı ilçelerinde balık tüketim alışkanlıklarının karşılaştırmalı olarak incelenmesi. Ordu Üniversitesi Bilim Teknik Dergisi, 3(2): 18-28.

Çolakoğlu, F.A., İşmen, A., Özen, Ö., Çakır, F., Yığın, Ç., Ormancı, H.B. (2006). Çanakkale ilindeki su ürünleri tüketim davranışlarının değerlendirilmesi. Ege Üniversitesi Su Ürünleri Dergisi, 23(3): 387392.

Dağtekin, M., Ak, O. (2007). Doğu Karadeniz Bölgesinde Su Ürünleri Tüketimi İhracat ve İthalat Potansiyeli. Sümae Yunus Araştırma Bülteni, 7(3):14-16.

Hecer, C. (2012). Türkiye'de Balıkçılık Sektörüne ve Türk Halkının Su Ürünleri
Tüketim Alışkanlıklarına Genel Bir Bakiş" An Overwiev To Turkish Sea Foods Sector and Consumption Habits of Turkish Consumers". Uludăg Üniversitesi Veteriner Fakültesi Dergisi, 31(2).

Güney, O.İ. Sangün, L. (2017). Olive Oil Consumption Attitudes: Millennials Vs NonMillennials. International Journal Of Natural And Engineering Sciences. 11 (2): 10-13.

Sangün, L., Güney, O.İ. (2018). Tüketicilerin Yumurta Satın Alma Davranış1: Türkiye Örneği. 3st International Mediterranean Science and Engineering Congress (IMSEC2018), Adana 1700-1703.

Sayılı, M., Esengün, K., Kayım, M., Akça, H. (1999). Tokat-Merkez İlçede Balık Tüketimini Etkileyen Faktörlerin Ekonometrik Analizi. GOÜ Ziraat Fakültesi Dergisi, 16(1): 9-28. 